\title{
AIR QUALITY AND CLIMATE CHANGE CO-BENEFITS FOR THE INDUSTRIAL SECTOR IN DURBAN, SOUTH AFRICA
}

Tirusha Thambiran ${ }^{1,2^{*}}$ and Roseanne D. Diab ${ }^{2}$

*Author for correspondence: tthambiran@csir.co.za

${ }^{1}$ CSIR Natural Resources and the Environment, PO Box 17001, Congella 4013, South Africa.

Telephone: +27312422368

Fax: +27312612509

${ }^{2}$ School of Environmental Sciences, University of KwaZulu-Natal, Westville Campus, Private Bag X 54001, Durban 4000, South Africa. 


\begin{abstract}
Industries in Durban, South Africa are a major source of air pollutant emissions and large users of fossil fuel based energy. Durban's energy strategy prioritises energy efficiency at industries as a key action, whilst industries are also the focus of the city's air quality management plan (AQMP). In this paper, measures that have been introduced in industries in Durban to effect air quality improvements and reduce energy consumption are examined in terms of their respective impacts on greenhouse gas (GHG) and air pollutant emissions. It was found that cobenefits for GHG mitigation were achieved when petroleum refineries switched from using heavy fuel oil to refinery gas and methane rich gas. Within other industries, co-benefits for air quality stemmed from reducing fossil fuel energy consumption and the improved efficiency of combustion systems. Air quality and energy policies in the city are being executed independently, without consideration of the trade-offs or synergies of the interventions being implemented. Recommendations are made for authorities and industries to consider the co-benefits for GHG mitigation in their AQMPs and where these are not possible to consider offsetting the increased GHG emissions through improved alignment with energy strategies.
\end{abstract}

Keywords: industrial sector; air quality management; energy consumption 


\section{Introduction}

Access to energy, in particular fossil fuel based energy, has been a key driver of economic and social development throughout the world (Bilgen et al., 2008; Quadrelli and Peterson, 2007), yet is simultaneously the root cause of contemporary environmental problems such as climate change, acid rain and urban smog. Despite the availability of non-fossil energy, the demand for fossil fuels continues to dominate the total primary energy supply (Quadrelli and Peterson, 2007). Due to its limited supplies and role in contemporary environmental problems, the use of fossil fuels is considered to be unsustainable (Wuebbles and Jain, 2001), placing the transformation of energy systems at the core of solutions for sustainable development. The management of fossil fuel consumption provides potential opportunities for environmental co-benefits, that is, the simultaneous reduction of air quality pollutants and greenhouse gas (GHG) emissions.

Due to a lack of co-ordination between air quality and energy policies, the cobenefits of energy policies could be offset by air quality management (AQM) processes and vice versa (Greening and Bernow, 2004). Streamlining air quality and energy policies to ensure co-ordinated and effective environmental solutions is an important argument that should define how the transition to a low carbon society evolves. This is especially relevant within a developing world context, where countries still experience significant air pollution challenges and are further anticipated to face substantial increases in their energy demand during the next 30 
years (Bauen, 2006). The development of AQM strategies that prioritise interventions with co-benefits for energy improvements could offer opportunities to achieve rapid environmental improvement.

Globally, the industrial sector is a major contributor to emissions of atmospheric pollution and a significant user of energy. Opportunities for simultaneously reducing energy consumption and air pollution emissions have been demonstrated by various types of industries (Worrell, and Galitsky, 2005) including those in developing countries (Aunan et al., 2004) indicating the multiple environmental and social benefits that are possible.

Harvesting co-benefits from policies that are originally developed to improve energy efficiency and reduce air pollution from fossil fuel use is particularly important in a country such as South Africa, where its industries are dependent on fossil fuels and the sustainability of its energy supplies has raised concerns over energy security (Büscher, 2009) and economic growth.

In the city of Durban, South Africa, industries are significant contributors to air pollution and are considered to be the sector with the largest energy demand. The development of AQM strategies that prioritise interventions with co-benefits for GHG mitigation could contribute towards South Africa's targets in respect of GHG emissions reductions. 
In this paper, measures that have been introduced in industries in Durban to effect air quality improvements are examined in terms of their impacts on energy usage and GHG emissions. In addition, reductions in fossil fuel based energy use by industry are considered in terms of their effects on air pollutant emissions. Section 2 provides a background to South African policy legislation pertaining to atmospheric emissions from the industrial sector. In Section 3, the case study of the industrial sector in Durban is presented, highlighting the implications of separate air quality and energy-saving interventions. In Section 4 the experiences from AQM and energy strategies are used to highlight recommendations for how future air quality targets should be approached by both industry and authorities. The role that industries can play in selecting intervention measures with cobenefits for climate change mitigation is presented in Section 5 , followed by concluding remarks in Section 6.

\section{Air quality and climate change policies in South Africa}

In the last decade there has been a change in the legislation governing air pollution in South Africa from the old Atmospheric Pollution Prevention Act (Act No. 45 of 1965) (the APPA) to the dramatically revised National Environmental Management: Air Quality Act (Act No.39 of 2004) (the AQA). The phasing in of the AQA through the development of the National Framework for Air Quality Management (NFAQM) in 2007 (DEAT, 2007) has allowed for the development of new ambient air quality and emission standards that are strongly focused on 
regulating emissions from industries. Since March 2010, when the AQA came into full effect, industries are required to manage their air pollution emissions to the atmosphere through this legislation.

Table 1 provides a brief comparison between the requirements of the AQA and the APPA as they relate to industries. The AQA specifies that the best practicable environmental option that could prevent, control, abate or mitigate pollution and protect society and the ambient air quality from harm must be implemented (DEAT, 2004). Activities that result in atmospheric emissions which have or may have a significant detrimental effect on the environment are designated as listed activities. Listed activities include for example, petroleum refining, metallurgical and mineral processing, and chemical industries (DEAT, 2007), and require an atmospheric emissions license (AEL) to operate. 
Table 1: A comparison of the APPA and the AQA as they relate to industries

\begin{tabular}{|c|c|c|c|}
\hline & $\begin{array}{l}\text { Classification } \\
\text { of industrial } \\
\text { activities }\end{array}$ & $\begin{array}{l}\text { Assessment criteria for issuing of } \\
\text { permits }\end{array}$ & $\begin{array}{l}\text { Regulation of } \\
\text { emissions }\end{array}$ \\
\hline The APPA & $\begin{array}{l}\text { Scheduled } \\
\text { processes }\end{array}$ & $\begin{array}{l}\text { Issue of Registration Certificates } \\
\text { - Best practicable means (BPM) } \\
\text { need to be taken to limit } \\
\text { emissions } \\
\text { BPM should consider the } \\
\text { prevailing extent of technical } \\
\text { knowledge of availabe control } \\
\text { options and the costs of } \\
\text { abatement }\end{array}$ & $\begin{array}{l}\text { No national emission } \\
\text { standards } \\
\text { No ambient air quality } \\
\text { standards }\end{array}$ \\
\hline The AQA & $\begin{array}{l}\text { Listed } \\
\text { activities }\end{array}$ & $\begin{array}{l}\text { Issue of Atmospheric Emission } \\
\text { Licenses } \\
\text { - Consideration of the pollution } \\
\text { that will likely result and the } \\
\text { possible effects on the } \\
\text { environment } \\
\text { Best practicable environmental } \\
\text { option is taken to prevent, } \\
\text { control, abate or mitigate } \\
\text { pollution } \\
\text { - Determination of whether or not } \\
\text { the applicant is a fit and proper } \\
\text { person, competent to manage the } \\
\text { listed activity }\end{array}$ & $\begin{array}{l}\text { Minimum emission } \\
\text { standards for priority } \\
\text { pollutants } \\
\text { Atmospheric impact } \\
\text { reports may be requested } \\
\text { if a person conducting a } \\
\text { listed activity fails to } \\
\text { comply with or is } \\
\text { suspected to contravene } \\
\text { conditions of the AEL or } \\
\text { the AQA prevention } \\
\text { Pollution for } \\
\text { plans are required for } \\
\text { activities that involve } \\
\text { emissions of priority } \\
\text { pollutants } \\
\text { National ambient air } \\
\text { quality standards }\end{array}$ \\
\hline
\end{tabular}

AELs are used as a means to regulate and ensure compliance with national minimum emission standards for air pollution. Minimum emission standards are included for pollutants such as nitrogen oxides $\left(\mathrm{NO}_{\mathrm{x}}\right)$, sulphur dioxide $\left(\mathrm{SO}_{2}\right)$ and particulate matter (PM). Such standards vary according to the type of operation and whether or not it is a new or existing source of emissions. Table 2 provides 
an example of emission standards for new solid fuel combustion installations. Existing plants are expected to reach the new plant limits within 10 years of the emissions standards coming into effect (SA, 2010).

Table 2: Example of emission standards for solid fuel combustion installations under the AQA (SA, 2010)

\begin{tabular}{|l|l|l|}
\hline Pollutant & Plant status & Emission standards $\mathbf{( m g / \mathbf { m } ^ { 3 } )}$ \\
\hline $\mathrm{PM}$ & Existing & 100 \\
\cline { 2 - 3 } & New & 50 \\
\hline $\mathrm{SO}_{2}$ & Existing & 3500 \\
\cline { 2 - 3 } & New & 500 \\
\hline $\mathrm{NO}_{\mathbf{x}}$ & Existing & 1100 \\
\cline { 2 - 3 } & New & 750 \\
\hline
\end{tabular}

Under the AQA, AELs require reporting on GHGs as well as the traditional air pollutants, thus requiring an AEL applicant to develop the capacity and expend resources to adequately report on GHG emissions.

In terms of climate change concerns, South Africa acceded to the Kyoto Protocol in 2002 and subsequently developed a national climate change response strategy in 2004 (DEAT, 2004). In 2006, a process that aimed to assess the potential for the mitigation of GHGs in the country began. This involved the development of a national GHG emissions inventory for the year 2000 (SA, 2009) and the 
subsequent long-term mitigation scenarios (LTMS). The LTMS highlighted industrial energy efficiency as key to GHG mitigation (SBT, 2007).

There are no national government policies currently in place to mitigate GHG emissions. Due to the nature of energy usage in the country, existing policies that aim to improve energy efficiency and promote renewable energy are being used to influence GHG emissions. However, due to the availability of inexpensive lowgrade coal and electricity tariffs that are amongst the lowest in the world (Winkler and Marquard, 2009), national energy policy, which has set renewable energy targets (DME, 2003), has failed to deliver significant adoption of solar and wind resources (Edkins et al., 2010). A Renewable Energy Feed-in Tarriff (REFIT) programme has been initiated to develop rewewable energy options, and other policies promoting solar water heating through the use of subsidies are also currently being rolled out (Edkins et al., 2010).

\section{Case study of the industrial sector in Durban}

The metropolitan area of Durban is the third largest urban area in South Africa. Industries contribute to over $22 \%$ of the city's Gross Domestic Product (GDP) (EM, 2009a). The industries include two petroleum refineries, a paper and pulp manufacturer, a large number of chemical industries and the largest motor vehicle manufacturer in southern Africa. The large concentration of process industries, particularly in the south of the city, has resulted in poor air quality that has given rise to many community complaints (Diab and Motha, 2007; Scott, 2003). 
Not surprisingly, the industrial sector has been identified as a priority area for intervention under the AQA and has had a long history of intervention even under the old APPA. Specifically, in 2000, the South Durban Multipoint Plan (SDMPP) was implemented to investigate and resolve the air pollution problems in the area. It provided a framework for the key role players in the area, that is, the major polluting industries, government and the community to address air pollution issues.

In 2007, the city's first Air Quality Management Plan (AQMP) was developed and gave formal expression, with the backing of legislation namely the AQA, to the management of ambient air quality. The history of interventions to improve air quality even before the promulgation of the AQA provides a useful platform from which to examine observed changes to ambient air quality and to consider the changes, if any, to GHG emissions.

The starting point for the consideration of the impacts of the industrial sector in Durban on air pollutant emissions, specifically $\mathrm{SO}_{2}$ and $\mathrm{NO}_{\mathrm{x}}$, and GHG emissions (carbon dioxide $\left(\mathrm{CO}_{2}\right)$ ) is the compilation of an emissions inventory.

\subsection{Emissions inventory for the industrial sector in Durban}

The inventory is based on energy consumption data. Many of the industries located in Durban are energy intensive, with energy-related costs responsible for 
between 10 to $50 \%$ of monthly operating expenses. Industrial energy supply has been dominated by fossil fuels as they have been easily available and relatively inexpensive. This has resulted in steam boilers and furnaces in industries being mostly dependent on fossil fuel combustion for the production of steam or generation of electricity. Renewable sources of energy such as biomass are used to a much smaller extent.

Data on energy consumption by industries for the year 2008 were obtained from major industries, city records and suppliers of coal and electricity to industries. Estimates of $\mathrm{SO}_{2}$ and $\mathrm{NO}_{\mathrm{x}}$ emissions from each energy source were derived from fuel consumption data and local and United States Environmental Protection Agency (US-EPA) air pollution emission factors (US-EPA, 1995). The IPCC (2006) guidelines were used for estimating $\mathrm{CO}_{2}$ emissions (Table 3). It must be noted that industries also produce significant air pollution and GHG emissions through manufacturing, other on-site processes and fugitive emissions. However, most industries do not have reliable estimates of direct GHG emissions, hence emission sources other than energy consumption have been excluded from this inventory. 
Table 3: Baseline air pollutant and GHG emissions for the industrial sector in Durban (tonnes per annum) for the year 2008

\begin{tabular}{|l|r|r|r|}
\hline Energy type & \multicolumn{1}{|l|}{$\mathbf{C O}_{\mathbf{2}}$} & \multicolumn{1}{l|}{$\mathbf{N O}_{\mathbf{x}}$} \\
\hline Coal & 1810427 & 10919 & 5409 \\
\hline Heavy fuel oil & 33918 & 777 & 65 \\
\hline Light fuel oil & 30906 & 395 & 75 \\
\hline Refinery gas & 1501218 & 124 & 1052 \\
\hline Paraffin gas & 102985 & 0.3 & 0.44 \\
\hline $\begin{array}{l}\text { Liquid petroleum } \\
\text { (LPG) }\end{array}$ & 249289 & 1.5 & 105 \\
\hline Methane rich gas (MRG) & 2713746 & 18883 & 11913 \\
\hline Electricity & 6559231 & 31108 & 19327 \\
\hline Total emissions & & & 708 \\
\hline
\end{tabular}

From this emissions inventory, it is evident that coal, refinery gas and electricity are the major contributors to GHG emissions in the industrial sector, contributing to $28 \%, 22 \%$ and $41 \%$ of the total $\mathrm{CO}_{2}$ emissions, respectively. Combustion of coal is further a significant contributor to local $\mathrm{SO}_{2}$ and $\mathrm{NO}_{\mathrm{x}}$. Refinery gas and methane rich gas (MRG) also contribute significantly to $\mathrm{NO}_{\mathrm{x}}$ emissions.

\subsection{Air pollution interventions}

Air pollution control measures are typically implemented, either through a change in the industrial process, switch in fuel or the installation of emission control equipment (Boubel et al., 1994). The application of these options generally varies 
according to the process and costs involved in respect of the atmospheric emission reductions that are required. The impacts of these measures for climate change are traditionally not considered in the decision to implement a control measure.

In Durban, the phasing out of dirty fuels and the use of improved pollution control technologies were two of the main measures used to reduce air pollutant emissions, resulting in a reduction of over $45 \%$ in $\mathrm{SO}_{2}$ emissions in the last decade (EM, 2007). A reduction in $\mathrm{SO}_{2}$ emissions was the major imperative of the SDMPP and no consideration was given to possible changes to GHG emissions. For the first time the full implication of these measures for climate change, specifically GHG emissions, is explored below.

\subsubsection{Change in fuel type at petroleum refineries}

Petroleum refining industries in the South Durban Industrial Basin (SDIB) switched from using predominantly heavy fuel oil (HFO) (3.5\% sulphur content) in heaters and boilers to using refinery gas ( 0.0001 to $0.015 \%$ sulphur content) and MRG (0.0003 to $0.0008 \%$ sulphur content) and were thus able to reduce their respective $\mathrm{SO}_{2}$ emissions from fuel combustion sources from over 40 tonnes per day to less than 2 tonnes per day (Engen, 2009; SAPREF, 2009). Environmental performance reviews for the major industries in the SDIB, as well as municipal environmental reports, together with information from Table 3 were used to assess the simultaneous impact of these fuel changes on $\mathrm{SO}_{2}$ and $\mathrm{CO}_{2}$ emissions. 


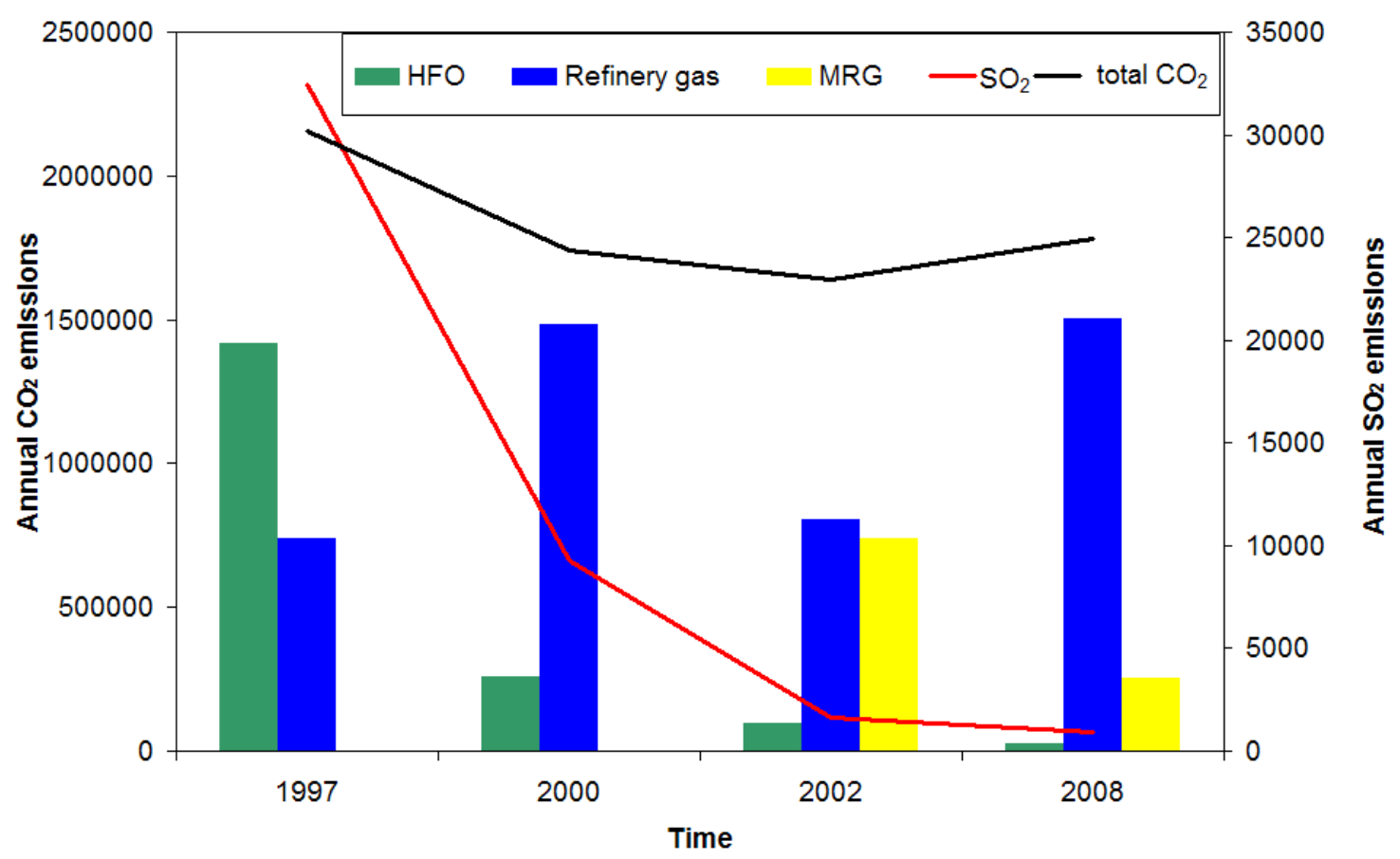

Figure 1: Changes in $\mathrm{CO}_{2}$ (solid black line) and $\mathrm{SO}_{2}$ emissions (solid red line) (in tonnes per annum) due to a change in fuels used at petroleum refineries within the SDIB

Figure 1 clearly depicts the decrease in $\mathrm{SO}_{2}$ emissions over the period 1997 to 2008, from over 32000 tonnes per annum to less than 1000 tonnes per annum, which enabled annual $\mathrm{SO}_{2}$ ambient air quality targets to be met. $\mathrm{CO}_{2}$ emissions are depicted separately for each of the fuel types (HFO, refinery gas and MRG), as well as cumulative totals. It is noted that there has been an overall decrease in GHG emissions over the 1997 to 2008 period, with an increase in emissions noted in 2008. The increase in emissions can be attributed primarily to changes at the petroleum refineries that occurred due to the implementation of the governmentlegislated improvements in fuel quality, that is, phase 1 of Clean Fuels project in 
South Africa. This programme required petroleum refineries to phase out the use of lead as an additive in petrol and to reduce the sulphur content of fuels produced. Structural changes and the installation of new energy intensive equipment such as distillation towers and isomerisation units, were some of the measures undertaken to meet these requirements.

\subsubsection{Change in sulphur content of coal and the installation of emission control devices at other industries}

Further emission control measures introduced resulted in industries in south Durban switching from using high sulphur coal (>1\% sulphur content) to coal with lower sulphur content $(<0.8 \%$ sulphur). In some cases this had the effect of reducing $\mathrm{SO}_{2}$ emissions by up to $20 \%$. However, despite these changes there were still significant emissions $\mathrm{SO}_{2}$, requiring further air pollution control action to be taken. Typically, such action resulted in the installation of end-of-pipe technologies.

Air pollution reducing technologies play a fundamental role in air quality policies, reducing the volume of emissions that is generated from the processes on site, often with no modifications required to the industrial process or the fuels used. The installation of wash pit and circulating fluidized bed (CFB) scrubbers are examples of this. The use of such scrubbers contributed up to a $50 \%$ decrease in related $\mathrm{SO}_{2}$ emissions from coal combustion (Airey, 2009; Dale, 2008; Dale et al., 2009). The combination of switching to lower sulphur coal and using 
pollution control devices has contributed to a cumulative $\mathrm{SO}_{2}$ reduction of up to $70 \%$ from certain industrial sources.

However, it must be noted that such air pollution technologies also often result in a reduction in efficiency levels of the industry, increasing fuel use by 1 to $3 \%$ and thus can have significant trade-offs for GHGs, particularly if the fuel source is carbon intensive. No specific measures are documented by industries in the SDIB for off-setting the increase in energy consumption due to the installation of these pollution control devices.

\subsection{Impact of energy consumption on air pollutant and GHG emissions}

As most industrial processes typically operate with energy intensities that are at least $50 \%$ greater than the theoretical minimum that can be achieved (Worrel et al., 2008), there is significant scope for energy efficient improvements to be implemented to improve operational efficiency and hence reduce costs and environmental impacts. Energy efficiency at industries has a vital role to play in developing effective pollution control policies, with GHG emission reductions of 10 to $30 \%$ possible (Saidur et al., 2008).

In Durban, authorities and industries have approached addressing issues related to energy consumption independently of air quality policy. Specifically, an energy strategy has been developed for the city, prioritising energy efficiency at 
industries as a key action. From an industry perspective, there have been various measures implemented to reduce fossil fuel consumption. These are considered in more detail below.

\subsubsection{Electricity-saving measures}

As there are no coal-fired power stations located in Durban, electricity is purchased by the city from the parastatal electricity supplier, Eskom. The supply of electricity to the city rose by over $25 \%$ during the period 1994 to 2004 , with the industrial sector being the largest user of electricity in the city (EM, 2006).

Durban, similar to the rest of the country, has in recent years experienced electricity supply shortfalls with rolling blackouts since late 2005, which reached crisis levels in 2008 (Sebitosi and Pillay, 2008). This resulted in the interruption of supply of energy due to a lack of electricity to meet the demand, a process commonly referred to as load shedding (Büscher, 2009). In light of these electricity shortfalls, large industrial consumers of electricity were requested to reduce their consumption by $10 \%$ (EM, 2009b). Industrial electricity consumption data for 2007 used were compared to data for 2008. It was found that only $45 \%$ of industries reduced their electricity consumption during this period. On average it was found that industrial electricity consumption decreased by $3 \%$. Those industries that managed to reduce their electricity consumption did so by conducting energy audits and identifying opportunities for reductions in 
electricity consumption. Specifically, measures such as improving lighting, and installing solar water heating for canteens and ablution facilities enabled significant reductions in electricity consumption. The electricity-savings have been well documented as successful energy-saving measures by the city (EM, 2009b). The reduction of electricity consumption in 2008 resulted in marked decreases in GHGs and some air pollutants (Table 4.4).

Table 4: Air pollution and GHG emission reductions (in tonnes) from electricity-saving measures in 2008 compared to 2007

\begin{tabular}{|l|r|r|r|r|}
\hline Intervention & \multicolumn{1}{|l|}{ Savings (South } & \multicolumn{1}{|l|}{$\mathrm{CO}_{2}$} & $\mathrm{SO}_{2}$ & $\mathrm{NO}_{\mathrm{x}}$ \\
& African rands) & & & \\
\hline Industrial electricity reduction & 23071410 & 69913 & 608 & 307 \\
\hline
\end{tabular}

In addition to these measures, there are other long-term projects, aimed at reducing electricity consumption to curtail costs, that have been initiated. Some industries in the city have begun to take advantage of opportunities to capture excess heat from primary combustion, for use as heat and power in a secondary process. This method of generating energy is commonly referred to as combined heat and power (CHP) or cogeneration. $\mathrm{CHP}$ is an option that allows for increased efficiency by removing or reducing the need for a fuel source in the second process. CHP provides a more energy efficient option than producing separate heat and power, often with the secondary benefit of reduced air pollution. However, the extent of the GHG and air pollution mitigation will vary according 
to the fuel used for primary energy generation and the air pollution controls that are implemented. Typical examples of CHP within the city include the recovery of steam which is fed back into the electrical system. In some instances it is reported that industries have been able to reduce electrical grid consumption by $10 \%$.

It is important to recognise that whilst such electricity-saving measures result in lower atmospheric emission levels at the power plants, such measures can only contribute toward indirect GHG emission reductions for the city (Mestl et al., 2005) in accordance with international protocols established to guide the development of local GHG emissions inventories (WRI, 2009). Furthermore, industries may be sceptical about investing in electricity reduction from the national grid as the air pollution benefits will not directly accrue to them. However, there are financial savings from reducing electricity consumption as shown in Table 4 and it further presents the opportunity to offset increases in GHG emissions due to air pollution interventions (discussed later).

\subsubsection{Improving the efficiency of combustion systems}

Combustion systems in industries represent a significant source of on-site emissions. It is well established that measures such as reducing stack temperature can result in improvements in the efficiency of a combustion system such as a boiler (Jaber, 2002). Other options such as replacing old and obsolete boilers with 
new efficient ones (Einstein et al., 2001; Jaber, 2002), modifications to the boiler design to a multilayer combustion system and boiler management all have the potential to improve efficiency and thus contribute to significant emission reductions (Aunan et al., 2004).

Further, it has been found that the efficiency of boilers varies according to the fuel type that is used (Einstein et al., 2001). A combination of increased boiler efficiency and change in fuels has been shown to have significant co-benefits (Jou et al., 2008). Thus a combination of improving boiler efficiencies together with certain fuel changes could lead to significant emission reductions.

Boilers used in the city of Durban are typically of the gas fire-tube or water-tube type and are estimated to be older than 30 years. On average, the combustion efficiency of the boilers is high, though the major fuel sources of the boilers include coal and MRG. Industries within the city have demonstrated that a thorough understanding of steam or heat requirements of specific processes can lead to more efficient use of the fuel that is used (EM, 2009b), and thus result in emission reductions.

A good example of this intervention is that of a chemical company in Durban that switched from using coal in its boilers to MRG. The industry further made changes to the boiler systems by replacing a $12 \mathrm{t} / \mathrm{hr}$ at 10 bar water tube coal boiler that had an efficiency of $68 \%$ with a $30 \mathrm{t} / \mathrm{hr}$ at 13 bar gas fired tube boiler with an efficiency of $93 \%$. The fuel switch from coal to MRG resulted in a power 
consumption reduction in the boiler house of $200 \mathrm{~kW}$, with a reduction of $37 \%$ in $\mathrm{CO}_{2}$ emissions and $81 \%$ in $\mathrm{SO}_{2}$ emissions (NCP, 2008). Whilst this intervention was successful, it may not be easily translated to other industries, as the cost of the alternate fuel and retrofitting the boilers are important considerations.

\subsection{Summary of the impacts of air quality and energy policies implemented by industries}

In summary, interventions in the industrial sector in Durban stem from the implementation of air quality policy, aimed at improving ambient air quality, and implementation of the city's energy strategy, designed to reduce energy consumption through improving energy efficiency. Although closely linked, air quality and energy policies in the city are being executed independently, without consideration of the trade-offs or synergies for climate change and air pollution respectively. In the case of air quality, the reduction of $\mathrm{SO}_{2}$ emissions has been of critical importance for improving the ambient air quality in the SDIB. However, the installation of end of pipe technologies and switching to fossil fuels with lower sulphur contents has allowed industries to continue to use fuel sources such as coal and refinery gas, which are significant contributors to $\mathrm{CO}_{2}$ emissions in Durban (Table 3). Reduction in electricity consumption by industries has been prioritised by the city's energy strategy, despite being responsible for $41 \%$ of $\mathrm{CO}_{2}$ emissions from this sector. Energy-saving measures thus have not been aligned with the city's AQMP nor promoted for the co-benefits that may be achieved. 


\section{The role of legislation in promoting co-benefits and the potential impact of future air pollution control on climate change}

There are often multiple legislative drivers (Taylor, 2006) that influence the approach that an industry will take to improve its environmental performance. The types of regulations implemented may impact on an industry's decision to adopt air pollution control technologies or undertake changes to its operations (Khanna et al., 2009). A total replacement of end-of-pipe technologies by cleaner production or structural measures is not always possible. In practice there will always be a mix of end-of-pipe technologies and cleaner production (Frondel, 2004). A key determining factor in the approach taken by an industry could be the timeline to expected emission reductions and the cost-effectiveness of meeting legislated targets. Of critical importance is that there is likely to be a significant time lag for an industry to develop an air pollution control plan and then effectively implement it.

Command and control policies are thought to impose regulatory frameworks with compliance timetables that can only be met through end-of-pipe abatement measures, preventing the adoption of in-plant cleaner production (Frondel, 2004; Taylor, 2006). The role that air quality regulations play in initiating innovative approaches to air pollution control, will be critical in determining if industries in Durban are successful in adopting air pollution measures with co-benefits for climate change. Lessons learnt from the reduction of $\mathrm{SO}_{2}$ emissions in the city and energy efficiency improvements made by industry indicate the trade-offs and 
synergies between interventions that can be used to guide future interventions in this sector. The implications of new emission standards under the AQA and expected changes to fuels produced in South Africa are considered below.

\subsection{New emission standards under the AQA}

The AQA has defined requirements for industries to meet emission standards for new and existing plants which could present significant challenges to achieving co-benefits. In light of new emission standards, the focus of future emission reduction projects by industries in the city is likely to be on $\mathrm{NO}_{\mathrm{x}}$ and $\mathrm{PM}$ emissions. Tables 5 and 6 show the relative impacts of replacing the higher polluting fuels such as coal and refinery gas, with other fuel sources such as MRG and biomass.

Table 5: The relative impacts on air pollutant and greenhouse gas emissions (tonnes per annum) of replacing coal used in industry with either MRG or biomass

\begin{tabular}{|c|c|c|c|c|}
\hline & $\mathrm{CO}_{2}$ & $\mathrm{SO}_{2}$ & $\mathbf{N O}_{\mathbf{x}}$ & $\mathbf{P M}$ \\
\hline Coal & 1810427 & 10919 & 5409 & 2957 \\
\hline MRG & 1145783 & 38 & 3265 & 62 \\
\hline Biomass (wood) & 0 & 958 & 1915 & 22091 \\
\hline
\end{tabular}


Table 6: The relative impacts on air pollutant and greenhouse gas emissions (tonnes per annum) of replacing refinery gas used in industry with either MRG or biomass

\begin{tabular}{|l|l|l|l|l|}
\hline & $\mathbf{C O}_{\mathbf{2}}$ & $\mathbf{S O}_{\mathbf{2}}$ & $\mathbf{N O}_{\mathbf{x}}$ & PM \\
\hline Refinery gas & 1501218 & 124 & 1052 & 63 \\
\hline MRG & 1375653 & 46 & 3909 & 74 \\
\hline Biomass (wood) & 0 & 1150 & 2230 & 26522 \\
\hline
\end{tabular}

Due to the presence of paper and pulp mills in the city, an attractive option from the perspective of industrial climate change mitigation is the use of renewable energy sources such as wood in boilers and furnaces. Biomass is generally viewed as being carbon neutral as the $\mathrm{CO}_{2}$ released from the fuel when burnt is equivalent to the amount of $\mathrm{CO}_{2}$ taken up by the tree during its lifetime (Saidur et al., 2011). Biomass usage may thus mitigate further $\mathrm{CO}_{2}$ emissions. However, the method by which the energy from biomass sources is extracted could have implications for air quality as demonstrated by policy in the United Kingdom, which promoted the usage of wood chips in biomass boilers and in so doing offset the air quality improvements from air pollution specific control measures (Hayes et al., 2008).

In the case of the AQA, the combustion of wood biomass would be required to meet the same PM and $\mathrm{NO}_{\mathrm{x}}$ emission standards as is the case for other solid fuels. Thus, promoting the use of biomass in boilers could offer co-benefits, if standards for PM emissions are well regulated. 
There are other factors, however, that will influence an industry's decision. The costs of fuels (Table 7) and the structural changes that would be required are likely to be key determining factors. Many of the larger manufacturing/process industries are already established in the city and have been designed to operate using specific raw materials. To meet the emission standards for existing plants, industries may opt to retrofit technologies to reduce emissions. The new legislation for $\mathrm{NO}_{\mathrm{x}}$ and $\mathrm{PM}$ emissions under the AQA could thus result in industries opting to use end-of-pipe technologies as opposed to fuel switching or structural changes, with significant implications for climate change.

Table 7: Typical costs of different forms of energy (AES, 2010)

\begin{tabular}{|l|l|}
\hline Type of energy & Costs (Rands/GJ) \\
\hline Refinery Gas & 0 (waste product) \\
\hline Coal & 25.5 \\
\hline MRG & $35-60$ \\
\hline Heavy fuel oil & 74 \\
\hline
\end{tabular}

$\mathrm{NO}_{\mathrm{x}}$ control options such as fluidized bed combustion represent a convenient option to reduce $\mathrm{NO}_{\mathrm{x}}$ and $\mathrm{PM}$ emissions. However, it has been shown that such measures could actually increase nitrous oxide $\left(\mathrm{N}_{2} \mathrm{O}\right)$ emissions. Selective catalytic reduction (SCR), another commonly used measure in stationary combustion appliances, reduces $\mathrm{NO}_{\mathrm{x}}$ but also has emission by-products that include ammonia $\left(\mathrm{NH}_{3}\right)$ and $\mathrm{N}_{2} \mathrm{O}$ (Winiwarter, 2005). The installation of electrostatic precipitators (ESP) is another common end-of-pipe device used to reduce $\mathrm{PM}$ emissions, but also has the effect of reducing the efficiency of the 
plant. As has been noted in respect of $\mathrm{SO}_{2}$, the installation of end-of-pipe technologies and switching to lower polluting fuels does not offer long-term solutions that benefit climate change. However, these pollution control technologies are regarded as being critical to prevent compromising economic growth (Hammar and Löfgren, 2010), which is particularly relevant within the context of a city in a developing country.

\subsection{Clean fuels programme in South Africa}

Globally, stricter regulations are being implemented to lower the sulphur content of petroleum products with concurrent development of advanced vehicle technologies. Petroleum refineries in countries such as those in Australia have reported potential increases in $\mathrm{CO}_{2}$ emissions as a result of adapting their refineries for the production of petroleum products with lower sulphur content (Shell, 2008). According to DEFRA (2007), such increases in $\mathrm{CO}_{2}$ emissions at refineries could be offset by improved technologies in petrol vehicles, though this is not robustly understood within a developing world context.

It is widely anticipated that within the next 10 years the South African government is likely to implement Clean Fuels 2 specifications (SA, 2003). This will require further reductions to the sulphur content of diesel and petrol that is manufactured in the country. The Clean Fuels initiative is seen as an imperative for reducing road transport-related emissions, as it will allow for the manufacture of petroleum products that contain less harmful air pollutants. It will further 
permit the introduction into the country of motor vehicles with advanced pollution control technologies and allow existing motor vehicles with such technologies to operate more efficiently. As Durban has two operating petroleum refineries within its jurisdiction, the climate change impact of implementing changes at industrial sites to facilitate the refining of cleaner fuels needs to be considered.

In order to meet these new fuel specifications, capital and operational costs at petroleum refineries in the city would be expected to increase. The current desulphurization techniques for petroleum products use significant amounts of hydrogen, which is an energy intensive product, with higher energy consumption and higher emissions of $\mathrm{CO}_{2}$ also occurring (Szklo and Schaeffer, 2007). Specifically, the installations of equipment such as hydrocrackers are likely to be required. There are some uncertainties as to whether these increases in $\mathrm{CO}_{2}$ are experienced only in the short-term or will continue throughout the operation of the plant.

In order to avoid increases in $\mathrm{CO}_{2}$ emissions, it is suggested that alternative desulphurization techniques such as biodesulphurization and oxidative desulphurization could be used. The use of biodesulphurization techniques can produce $70-80 \%$ lower $\mathrm{CO}_{2}$ emissions than conventional methods, and has lower operational costs (Soleimani et al. 2007), however the use of such techniques still face some challenges. 
Expected $\mathrm{CO}_{2}$ emissions increases from these process changes can only be determined once the Clean Fuels 2 emissions standards are released and the petroleum refineries are able to assess how it will affect their operations and energy consumption. From the experience of implementing the first phase of this project, namely Cleans Fuels 1 , it is estimated that the annual $\mathrm{CO}_{2}$ emissions from the petrochemical refineries in Durban increased by over $8 \%$ (Fig. 1).

The timing of the introduction of cleaner fuel standards in South Africa has to be assessed carefully according to the likely impacts on refinery emissions and the time delay in seeing an effect in the road transport sector due to the ageing motor vehicle fleet. Further, this needs to be considered alongside the AQA requirements for $\mathrm{PM}$ and $\mathrm{NO}_{\mathrm{x}}$ emission reductions required by these industries, taking cognisance of where the maximum benefit for the environment can be achieved and thus prioritised for investment.

\section{Combining energy policies and air quality interventions to support a low- carbon society}

Worrel and Price (2001) raise an important point, that industrial policies are never implemented in isolation, as individual policies may have feedback effects, which can impact on the effectiveness of other policies. An understanding of the impact of the air quality control strategies on other air pollutants and GHG emissions is necessary for stakeholders to select and implement those air quality control measures that can support GHG mitigation efforts and avoid those that may act to 
offset the GHG reductions obtained from energy or climate change specific mitigation strategies.

Industries may take different routes to meeting air quality targets. These can vary from a minimalist approach that seeks to reduce any trade-offs for climate change, to one that maximises any synergies that may be present within the system and avoids trade-offs. With the former approach, if an air pollution intervention results in increases in GHG emissions, measures should be taken to offset this (Fig. 2). In such a case if an industry decides to install an end-of-pipe technology, it may offset the increases in energy consumption by improving energy efficiency elsewhere within the plant. An energy loss management system for example could be implemented to ensure that the industry is fully aware of opportunities within the plant to offset the impacts of its air quality actions. 


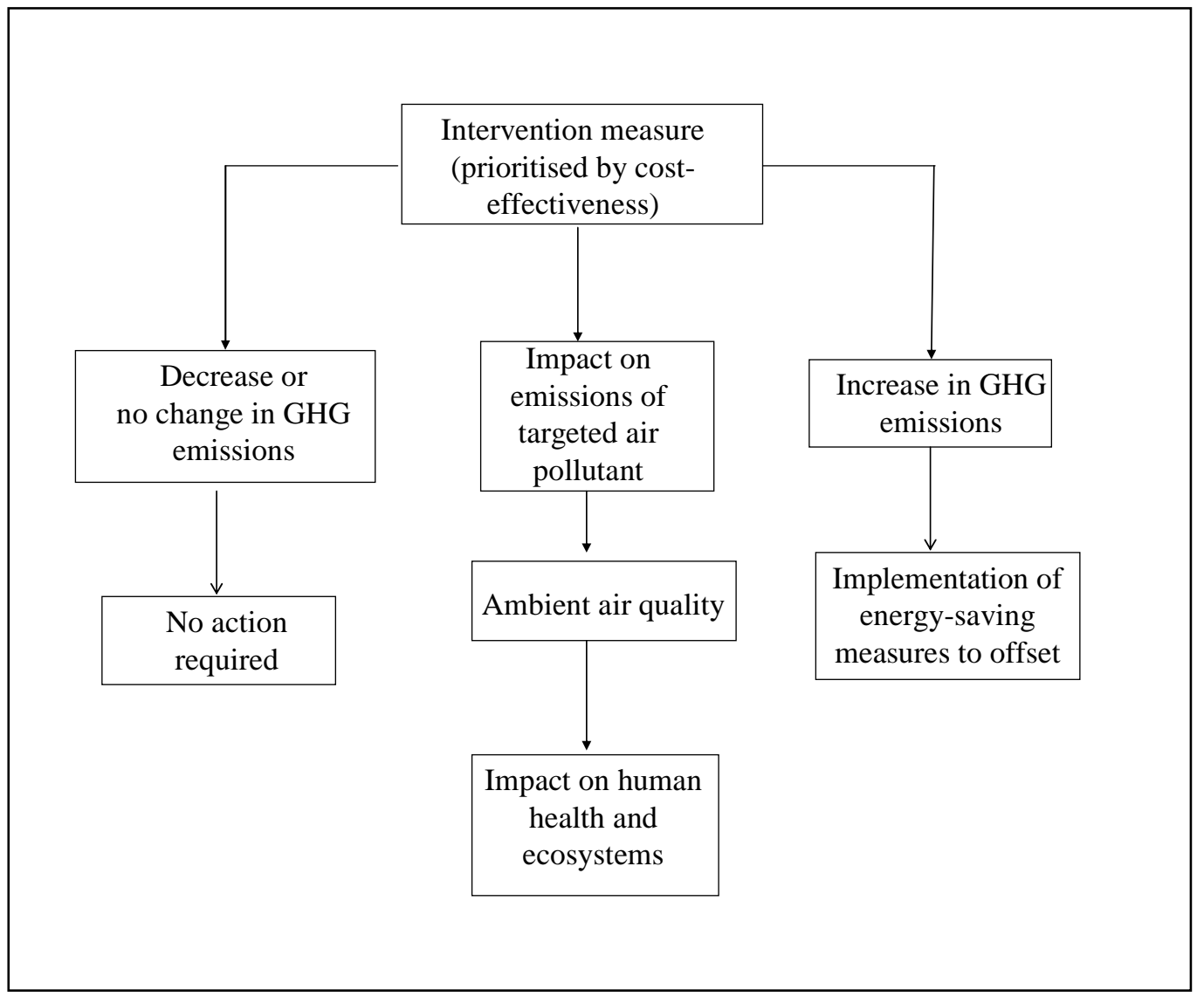

Figure 2: Minimalist approach to achieving co-benefits for climate change mitigation from $A Q M$ interventions

However, if the industry wants to maximise any synergies and best utilise opportunities to simultaneously reduce its carbon footprint through its air quality initiatives, it will have to consider the impact of the intervention for the targeted pollutant and other atmospheric emissions, and the overall impact for climate change (Fig. 3). When selecting an intervention measure to meet air quality targets, there need to be criteria in place to ensure that the complex climate change linkages and interactions that exist between these two issues are considered. Measures selected will have to focus on switching to lower carbon fuels and improving industrial efficiency. This will be especially relevant to those new industries that are designing their plants to achieve the prescribed emission limits 
for air quality. Industries that undertake air quality interventions that verifiably mitigate GHG emissions should be credited for early action once specific GHG mitigation policy is implemented in the city.

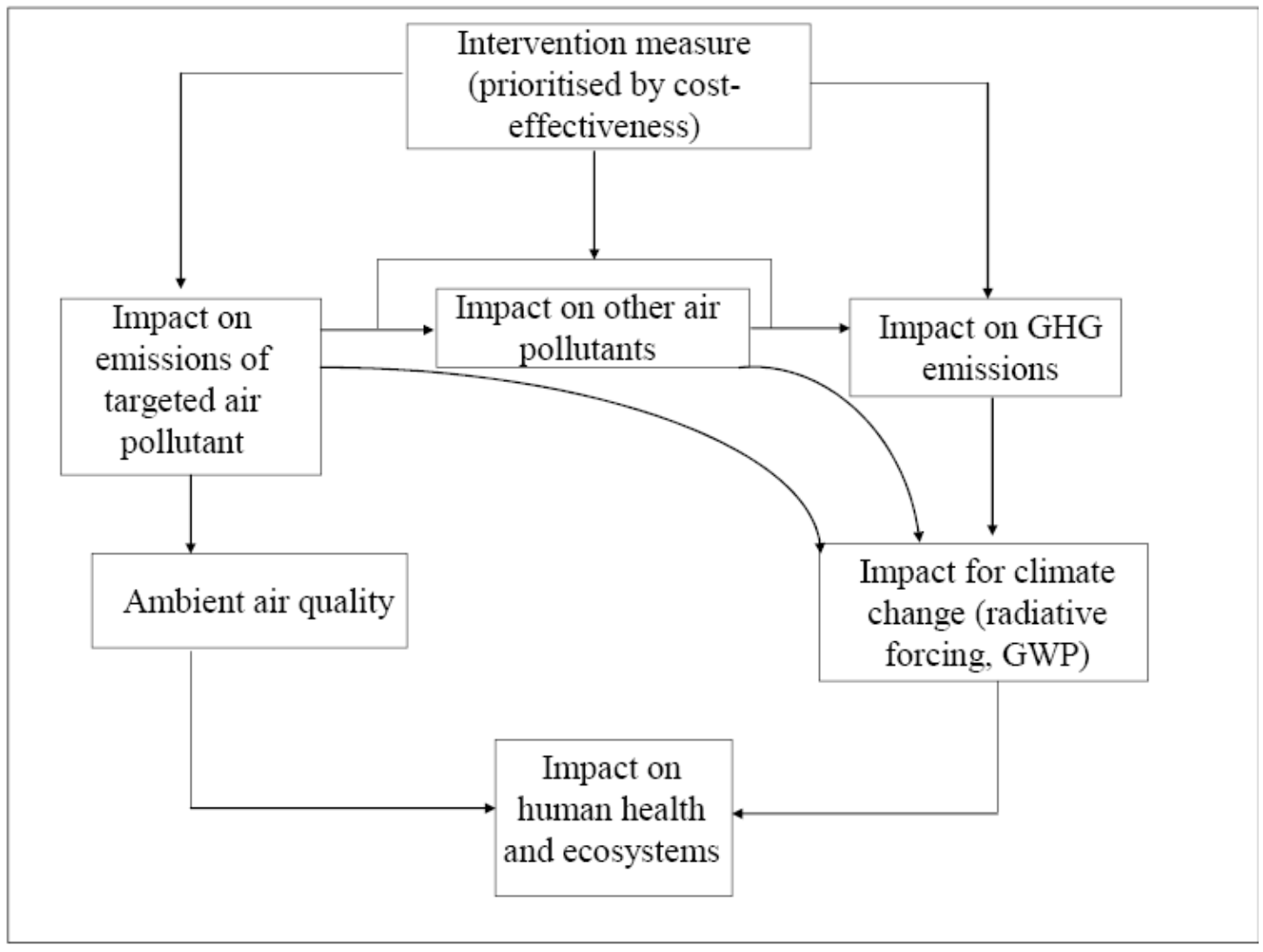

Figure 3: Expanded approach to achieving co-benefits for climate change mitigation from $A Q M$ interventions

\section{Discussion and concluding remarks}

Energy consumption is one of the important sources of GHG emissions within the industrial sector in Durban. However, the primary concern of industries has been dealing with air pollution and being compliant with other legislation that may apply to their operations. As GHG emissions are not regulated by any specific 
national legislation or by-laws within the city, there has been little incentive for industries to focus on reducing GHG emissions through measures targeted at improving air quality. Therefore, industrial measures that have contributed toward GHG mitigation have been primarily as a result of cost-savings measures on the part of the industry and demand management of electricity consumption as required by the national government.

Furthermore, whilst the synergistic effects of air quality and fuel savings are in the most part documented, the trade-offs that occur, such as the increased electricity consumption from the installation of air pollution cleaning devices are often not quantified and not taken into account in the decision to implement a control measure. Furthermore, in these instances, measures to offset any of the increases in GHG emissions were not implemented.

New air quality related legislation applicable to industries has the potential to impact on GHG emissions. Measures taken to ensure compliance with new emission standards should ideally have co-benefits for simultaneously reducing GHG emissions. If this is not the case, industries should ensure that measures to offset GHG increases from air pollution measures are implemented. In addition, it must be borne in mind that the benefits of reducing fossil fuel consumption on site will result in both direct air quality benefits and GHG emission reductions. The city thus has a responsibility to promote or incentivise investment in onsite energy combustion efficiency. This is especially relevant in areas of the city where 
industries are located in proximity to residential areas and ambient air quality standards are currently being, or could potentially be exceeded.

Air quality officials in Durban have established the capacity to collect and maintain air pollution emission databases. Additional training and support of air quality officials in instituting programmes to monitor GHG emissions and perform assessments of co-benefits or trade-offs that exist from air quality interventions is needed. Furthermore, the contribution of industrial processes (non-energy) to GHG emissions may be poorly understood and is not quantified by all industries. This represents an important source of emissions that requires reliable estimates to be made. The capacity of industries to adequately report on GHG emissions and the costs of report also needs to be assessed.

Finally, at higher spheres of government, action needs to be taken to set up a regulatory framework to promote the adoption of air quality measures with cobenefits. Industries that have or will undertake air quality interventions that verifiably mitigate against GHG emissions should be credited for early action once specific GHG mitigation policy is implemented in the city.

\section{References}

Airey, D. (2009). $\mathrm{SO}_{2}$ reductions at a chemical dissolving pulp mill. Technical Association of the pulp and paper industry of the pulp and paper industry of southern Africa. Available at: http://www.tappsa.co.za/archive3/Journal_papers/journal_papers.html Date accessed: 3 February 2010. 
Associated Energy Services (AES). (2010). Industry overview. Available at: http://www.aesafrica.com/information.php?file=AES_Industry_Overview Data accessed: 6 June 2010.

Aunan, K., Fang, J., Vennemo, H., Oye, K. and Seip, H.M. (2004). Co-benefits of climate policylessons learned from a study in Shanxi, China. Energy Policy, 32, 567-581.

Bauen, A. (2006). Future energy sources and systems - Acting on climate change and energy security. Journal of Power Sources, 157, 893 -901.

Boubel, R.W., Fox, D.L., Turner, D.B., and Stern, A.C. (1994). Fundamentals of Air Pollution, Third Edition, Academic Press, San Diego.

Bilgen, S., Keles, S., Kaygusuz, A., Sari, A. And Kaygusuz, K. (2008). Global warming and renewable energy sources for sustainable development: A case study in Turkey. Renewable and Sustainable Energy Reviews, 12, 372-386.

Büscher, B. (2009). Connecting political economies of energy in South Africa. Energy Policy, doi:10.1016/j.enpol.2009.04.041.

Dale, B. (2008). eThekwini scheduled trade permitting system. $3^{\text {rd }}$ Annual Air Quality Lekgotla, Nelspruit, South Africa.

Dale, B., Maharaj, S., and Khan, W. (2009). Development of the SAPPI Saiccor scheduled trade permit. $4^{\text {th }}$ Annual Air Quailty Lekgotla, 12 October 2009. Vanderbijlpark, South Africa.

Department of Environmental Affairs and Tourism (DEAT). (2004). A national climate change response ftrategy for South Africa. Available http://unfccc.int/files/meetings/seminar/.../sem_sup3_south_africa.pdf Date accessed: 27 February 2007. 
Department of Environmental Affairs and Tourism (DEAT). (2007). The national framework for air quality management in the Republic of South Africa; 2007. Available at: http://www.saaqis.org.za/Downloads.aspx?type=AQ Date accessed: 28 April 2009.

Department for Environment, Food and Rural Affairs (DEFRA). (2007). Air quality and climate change: A UK perspective. Available at: www.defra.gov.uk/environment/airquality/aqeg Date assessed: 10 April 2008.

Department of Minerals and Energy (DME). (2003). White Paper on the Renewable Energy Policy of the Republic of South Africa. Department of Minerals and Energy, Pretoria

Diab, R.D. and Motha, A. (2007). An analysis of key institutional factors influencing air quality in South Durban using the DPSIR framework. South African Geographical Journal, 89(1), 22-33.

Edkins, M., Marquard, A. and Winkler, H. (2010). South Africa's renewable energy policy roadmaps. Final report for the United Nations Environment Programme Research Project: Enhancing information for renewable energy technology deployment in Brazil, China and South Africa. Energy Research Centre, University of Cape Town. 48pp.

eThekwini Municipality (EM). (2006). eThekwini Municipality: State of energy report. eThekwini Municipality Environmental Management Department. 151 pp. Available at: www.durban.gov.za/.../energy/ethekwini-municipality-state-of-energy-report?...eThekwiniPrint Date accessed: 13 March 2008.

eThekwini Municipality (EM). (2007). Air quality management plan for eThekwini Municipality, KwaZulu-Natal, South Africa.79pp.

eThekwini Municipality (EM). (2009a). Integrated Development Plan. 5 year plan 2006/07 to 2010/11, 2009/2010 Annual Review. 158pp. 
eThekwini Municipality (EM). (2009b). Saving electricity in commercial and industrial buildings and operations. A guide to reducing costs and helping to avoid load shedding. 66pp.

Engen. (2009). Environmental performance report 2008. Engen Refinery, Durban, South Africa. $65 \mathrm{pp}$.

Einstein, D., Worrell, E. and Khrushch, M. (2001). Steam systems in industry: Energy use and energy efficiency improvement potentials. Lawrence Berkeley National Laboratory, Berkeley, CA (US) Available at: http://www.osti.gov/energycitations/product.biblio.jsp?osti_id=789187 Date accessed: 17 December, 2008.

Frondel, M., Horbach, J. and Rennings, K. (2004). End-of-pipe or cleaner production? An empirical comparison of environmental innovation decisions across OECD countries. Discussion Paper No. 04-82. Centre fro European Economic Research. Available at: http://madoc.bib.unimannheim.de/madoc/volltexte/2005/932/pdf/dp0482.pdf Date accessed: 15 May 2010.

Greening, L.A. and Bernow, S. (2010). Design of coordinated energy and environmental policies: use of multi-criteria decision-making. Energy Policy, 32, 721-735.

Hammar, H. and Löfgren, A. (2010). Explaining adoption of end-of-pipe solutions and clean technologies - Determinants of firms' investments for reducing emissions to air in four sectors in Sweden. Energy Policy, 38, 3644-3651.

Hayes, E.T., Chatterton, T.J., Leksmono, N.S. and Longhurst, J.W.S. (2008). The potential impact from increase use of wood fuelled biomass on local air quality in London: Lessons to exchange with mega-cities in developing countries. Proceedings of the $16^{\text {th }}$ Annual IUAPPA regional conference, 1-3 October, 2008, Nelspruit. 
Intergovernmental Panel on Climate Change (IPCC). (2006). In: Eggleston, H.S., Buendia, L., Miwa, K., Ngara, T., Tanabe, K. (eds.), IPCC guidelines for national greenhouse gas inventories. Prepared by the National Greenhouse Gas Inventories Programme. IGES, Japan.

Jaber, J.O. (2002). Future energy consumption and greenhouse gas emissions in Jordanian industries. Applied Energy, 71, 15-30.

Jou. C-J.G., Lee, C-1., Tsai, C-H. and Wang, H.P. (2008). Reduction of energy cost and $\mathrm{CO}_{2}$ Emission for the boilers in a full-scale refinery plant by adding waste hyrdogen-rich fuel gas. Energy Fuels, 22(1), 564-569.

Khanna, M., Deltas, G. and Harrington, D.R. (2009). Adoption of pollution prevention techniques: The role of management systems and regulatory pressures. Environment Research Economics, 44, 85-106.

Mestl, H.E., Aunan, K., Fang, J., Seip, H.M., Skjelvik, J.M. and Vennemo, H. (2005). Cleaner production as climate investment - integrated assessment in Taiyuan City, China. Journal of Cleaner Production, 13, 57-70.

NCP. (2008). Sustainability report 2008. NCP Alcohols, Durban, South Africa. 26pp.

Quadrelli, R. and Peterson, S. (2007). The energy-climate challenge: Recent trends in $\mathrm{CO}_{2}$ emissions from fuel combustion. Energy Policy, 35, 5938-5952.

Saidur, R., Rahim, N.A., Masjuki, H.H., Mekhilef, S., Ping, H.W. and Jamaluddin, M.F. (2008). End-use energy analysis in the Malaysian industrial sector. Energy, doi: 10.1016/ j.energy.2008.11.004 
Saidur, R., Abdelaziz, E.A., Demirbas, A., Hossain, M.S. and Mekhilef, S. (2011). A review of biomass as a fuel for boilers. Renewable and Sutainable Energy Reviews, 15,2262-2289.

Sapref. (2009). Sustainability Report 2008 - A report to our stakeholders. Sapref, Durban, South Africa. 32pp.

Scenario Building Team (SBT). (2007). Long-term mitigation scenarios : Technical summary, Department of Environmental Affairs and Tourism, Pretoria, October 2007. 30pp.

Scott, D. (2003). 'Creative Destruction': Early modernist planning in the south Durban industrial zone, South Africa. Journal of Southern African Studies, 29 (1), 235-259.

Shell (2009). Environmental Performance : Reducing greenhouse gas emissions. Available at: http://www.shell.com.au/home/content/aus/environment_society/ Date accessed: 4 August 2008.

Soleimani, M., Bassi, A. and Margaritis, A. (2007). Biodesulfurization of refractory organic sulphur compounds in fossil fuels. Biotechnology Advances, 25, 570-596.

Szklo, A. and Schaeffer, R. (2007). Fuel specification, energy consumption and $\mathrm{CO}_{2}$ emission in oil refineries. Energy, 32, 1075-1092.

South Africa (SA). (2003). Final Draft: Joint implementation strategy for the control of exhaust emissions from road-going vehicles in the Republic South Africa. (Notice 3324 of 2003). Government Gazette 25741: 12 December 2003.

South Africa (SA). (2009). Greenhouse gas inventory. South Africa 1990-2000. Compilation under the United Nations Framework Convention on Climate Change (UNFCCC). Department Environment and Tourism, Republic of South Africa.103pp. 
South Africa (SA). (2010). Listed activities and associated minimum emission standards identified in terms of Section 21 of the National Environmental Management: Air Quality Act, 2004 (Act No 39. of 2004). Government Gazette, 537: 33064. 31 March 2010.

Taylor, B. (2006). Encouraging industry to assess and implement cleaner production measures. Journal of Cleaner Production, 14, 601-609.

United States Environmental Protection Agency (US-EPA). (1995). Compilation of air pollution emission factors (AP-42), 5th Edition, Volume 1, US Environmental Protection Agency, Research Triangle Park, North Carolina.

Winkler, H. and Marquard, A. (2009). Analysis of the economic implications of a carbon tax. Energy Research Centre, University of Cape Town. 22pp.

Winiwarter, W. (2005). The GAINS Model for greenhouse gases, version 1.0: nitrous oxide $\left(\mathrm{N}_{2} \mathrm{O}\right)$. IIIASA Interim Report IR-05055.

Worrell, E. and Galitsky, C. (2005). Energy efficiency improvement and cost saving opportunities for petroleum refineries. An ENERGY STAR Guide for Energy and Plant Managers. Available at: http://www.energystar.gov/index.cfm?c=industry.bus industry info_center\#petroleum Date accessed: 13 January, 2009.

Worrell, E. and Price, L. (2001). Policy scenarios for energy efficiency improvements in industry. Enery Policy, 29, 1223-1241.

Worrel, E., Bernstein, L., Roy, J., Price. L. and Harnisch, J. (2008). Industrial energy efficiency and climate change mitigation. Energy Efficiency, doi: 10.1007/s12053-008-9032-8 
World Research Institute (WRI). (2009). The greenhouse gas protocol. A corporate accounting and reporting standard. Revised edition. Available at: http://www.ghgprotocol.org/ Date accessed: 23 September 2009.

Wuebbles, D.J. and Jain, A.K. (2001). Concerns about climate change and the role of fossil fuel use. Fuel Processing Technology, 71, 99 -119. 